\title{
STRATEGI PENINGKATKAN SEMANGAT DAN KESADARAN MASYARAKAT DALAM MENERAPKAN PROTOKOL KESEHATAN PANDEMI COVID-19
}

\author{
Kartika Arum Wardani \\ D3 Analis Kesehatan, Kesehatan Masyarakat, STIKes Karya Putra Bangsa \\ Tulungagung
}

Email Korespondensi: arumkartika77@gmail.com

Disubmit: 11 November 2021 Diterima: 11 Desember $2021 \quad$ Diterbitkan: 02 Januari 2022 DOI: https://doi.org/10.33024/jkpm.v1i1.5461

\begin{abstract}
ABSTRAK
Pandemi Covid-19 belum berakhir, banyak masyarakat yang sudah mulai lelah dalam menghadapi situasi pandemi ini. Gaya hidup sehat pun mulai menurun. Kesadaran tanggung jawab antara keluarga baik orang tua dan anak juga semakin menurun. Banyak warga yang mengeluhkan kondisi pandemi yang tak kunjung selesai. Sehingga diperlukan strategi upaya untuk meningkatkan semangat dan juga kesadaran masyarakat di Indonesia khususnya di Desa Beji kecamatan Boyolangu-Tulungagung, beberapa upaya diantaranya melakukan sosilaisasi edukasi tentang pengenalan pandemi Covid-19 serta penerapan protokol kesehatan, sosialisasi peran tenaga kesehatan dan pemeriksaan Covid-19, strategi aktivitas pengantar orang tua dan anak. Hasil dari kegiatan menunjukkan adanya peningkatan pengetahuan sebesar $87 \%$, antusias pelaksanaan protokol kesehatan $55 \%$, dan pelaksanaan kartu aktivitas 2\%. Pentingnya dari hasil kegiatan ini diharapkannya dapat memacu motivasi masyarakat agar terus melaksanakan protokol kesehatan dan melakukan aktivitas positif di masa Pandemi.
\end{abstract}

Kata kunci : COVID-19, Protokol Kesehatan, Aktivitas Pandemi

\begin{abstract}
The Covid-19 pandemic is not over yet, many people are getting tired of dealing with this pandemic situation. Healthy lifestyles began to decline. Awareness of responsibility between families, both parents and children, is also decreasing. Many residents have complained about the ongoing pandemic. So that an effort strategy is needed to increase the enthusiasm and awareness of the people in Indonesia, especially in Beji Village, Boyolangu-Tulungagung sub-district, several efforts including conducting outreach education about the introduction of the Covid-19 pandemic and the application of health protocols, socialization of the role of health workers and Covid-19 checks, strategies parent and child introductory activities. The results of the activity showed an increase in knowledgment by $87 \%$, application of health protocol by $55 \%$, and effectivity of pandemic card about $2 \%$. The importance of the results of this activity is expected to spur people's motivation to continue to implement health protocols and carry out positive activities during the Pandemic.
\end{abstract}

Keywords: COVID-19, Health Protocols, Pandemic Activities 


\section{PENDAHULUAN}

Pandemi Covid-19 merupakan suatu penyakit infeksi yang disebabkan oleh virus corona spesies SARS-COV-2 yang menyerang saluran pernapasan akut, dapat menyebabkan kematian dan penyebarannya hampir di seluruh Negara. Penyakit Covid-19 ditemukan pertama kali, pada akhir bulan Desember 2019 silam, di Wuhan, China (Shereen et al., 2020; Tarigan \& Arum, 2020). Kemudian penyakit tersebut menyebar ke berbagai Negara termasuk di Indonesia. Covid-19 masuk ke Indonesia pada awal bulan Maret 2020, di kota Jakarta, selanjutnya ditemukan beberapa kasus serupa menyusul di kota-kota lainnya. Kasus pasien Covid-19 di Indonesia terus mengalami peningkatan hingga sekarang, Januari 2021 (Ayu et al., 2020; Satgas Penanganan COVID-19, 2020). Pemerintah sudah mengeluarkan beberapa program kesehatan yang wajib dilakukan oleh seluruh masyarakat Indonesia, seperti menggunakan masker, social distancing, mencuci tangan, bahkan PSBB (Pembatasan Sosial Berskala Besar). Program terbaru di tahun 2021 ialah berlakunya vaksin yang sudah mendapatkan ijin edar oleh pemerintah (RI, 2021). Tak terkecuali presiden juga akan melakukan vaksin pertama kali di Indonesia. Namun, bagi masyarakat sebaiknya tetap menerapkan program pemerintah seperti pakai masker, jaga jarak dan cuci tangan. Walaupun begitu, fakta di lapangan menunjukkan adanya penurunan antusiasme masyarakat Indonesia dalam menerapkan program tersebut (Nasruddin \& Haq, 2020).

Kasus pasien Covid-19 di Indonesia masih terbilang cukup tinggi termasuk di wilayah Jawa Timur. Kabupaten Tulungagung merupakan salah satu wilayah Jawa Timur yang termasuk ke dalam zona oranye (tingkat resiko sedang) dengan skor 1.98, kasus terkonfirmasi sebanyak $1676 \pm 29$, suspek 79 , sembuh $1313 \pm 45$ (78,34\%), dan meninggal 40 (2,39\%), per tanggal 13 Januari 2021. Meskipun jumlah kasus Covid-19 di kabupaten Tulungagung cukup tinggi namun kasus kematian cukup rendah (Beji, 2021; Dinkes, 2021). Sehingga pemerintah kabupaten Tulungagung terus mengupayakan dan menghimbau masyarakat agar tetap menerapkan protokol kesehatan dimanapun. Selain pemerintah, kami para civitas akademik STIKes Karya Putra Bangsa Tulungagung tergerak untuk ikut membantu program pemerintah sebagai bentuk pelaksanaan kegiatan tri dharma perguruan tinggi yaitu pengabdian masyarakat. Dari beberpa desa dan kecamatan di kabupaten kami tertarik melakukan pengabdian masyarakat di desa Beji, kecamatan Boyolangu. Diketahui di kecamatan Boyolangu terdapat 5 kasus baru berdasarkan data dinkes kabupaten Tulungagung per tanggal 12 Januari 2021 (Dinkes, 2021). Tidak menutup mata, meningkatnya jumlah kasus baru Covid-19 di wilayah tersebut di karenakan banyak warga yang mengabaikan protocol kesehatan dan mulai bosan dengan aturan-aturan pemerintah yang tak kunjung selesai dalam menangani pandemi. Hal tersebut kami ketahui dari hasil survey dan wawancara dengan beberapa warga sekitar kecamatan Boyolangu. Tujuan dari pengabdian Masyarakat ini adalah untuk memberikan edukasi dan motivasi kepada masyarakat dalam melaksanakan protocol kesehatan di era pandemi. 


\section{MASALAH}

Pandemi Covid-19 masih berlangsung hingga kini sehingga diperlukan semangat dan kesadaran tinggi terhadap upaya dalam menerapkan protocol kesehatan sesuai program pemerintah. Apabila masyarakat Tulungagung terutama desa Beji kecamatan Boyolangu saling bergotong royong dan saling membangun, peduli antar sesama dalam menerapkan protocol kesehatan dan ikut menyukseskan program pemerintah di masa pandemi maka optimism penurunan kasus Covid-19 di wilayah tersebut akan berkurang dan kemungkinan harapan Tulungagung menjadi zona hijau akan terwujud.

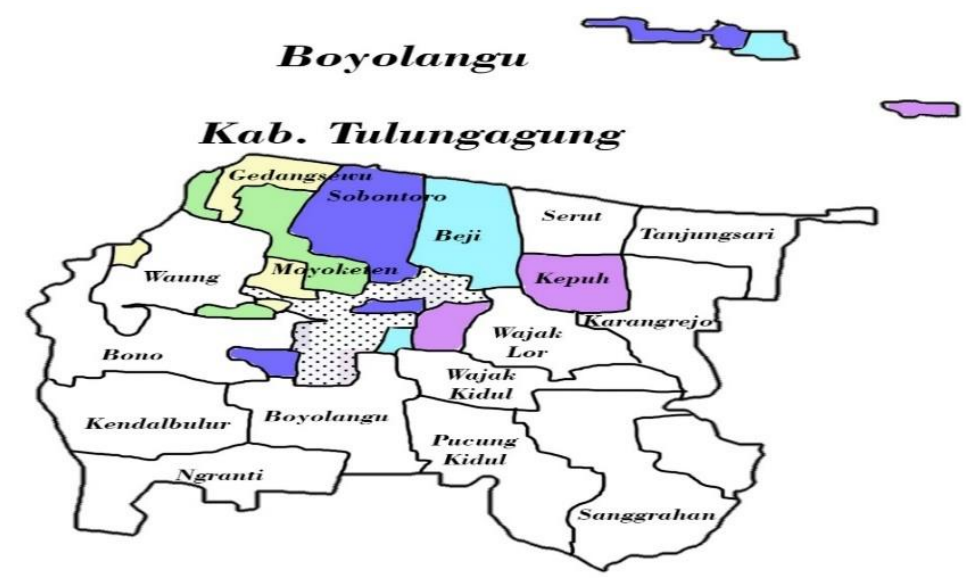

Gambar 2.1 Peta Lokasi Kegiatan. Desa Boyolangu Kabupaten Tulungagung

\section{METODELOGI PELAKSANAAN}

a) Tahap persiapan

Tahap pertama yang dilakukan dalam kegiatan ini adalah melakukan observasi kepada mitra dengan terjun langsung kepada mitra untuk mengetahui karakteristik, situasi penduduk, goegrafis secara menyeluruh. Dan menyiapkan perlengkapan seperti surat pengantar, surat mitra, surat pertanggungjawaban

b) Tahap Analisa

Tahap analisa dilakukan untuk mengetahui kebutuhan yang dibutuhkan oleh masyarakat, dengan memberikan kuesioner dan wawancara beberapa warga yang mengandung masalah utama dan solusi yang diharapkan oleh warga sekitar. Kuesioner yang digunakan yaitu kuesioner yang bersifat terbuka.

2)Tahap perencanaan kegiatan

Setelah mengumpulkan data dan kuesioner dari warga selanjutnya akan diolah dan dipilih masalah warga yang paling umum dan solusi yang mereka harapkan sesuai dengan bidang kami. Selain itu juga meminta masukan dari pamong desa dan juga tim/ pihak civitas pengabdian masyarakat STIKes Karya Putra Bangsa Tulungagung.

3) Tahap pelaksanaan

Untuk pelaksaan program Pengabdian Masyarakat sasaran dilakukan selama kurang lebih Maret-Mei 2021 di Desa Beji, Kecamatan Boyolangu, Kabupaten Tulungagung. 
Indikator keberhasilan program

Dari 15 warga yang mengikuti pengmas setidaknya memiliki pemahaman tentang pentingnya untuk selalu melaksanakan protocol kesehatan (tau tentang penyakit Covi-19 apa, penyebarannya seperti apa, mengapa perlu membiasakan menggunakan protocol kesehatan, perubahan perilaku, dan timbul rasa peduli dengan sesama tentang protocol kesehatan). Selain itu, kami mengupayakan menunjuk satu kader kesehatan yang akan meneruskan pengetahuan tentang strategi meningkatkan kesadaran masyarakat dalam melakukan protocol kesehatan.

\section{HASIL DAN PEMBAHASAN}

Sebagai upaya peningkatan penerapan protocol kesehatan di masa pandemi sesuai dengan Keputusan Menteri Kesehatan Republik Indonesianomor Hk.01.07/Menkes/382/2020, maka masyarakat perlu dilakukan pembinaan dan pemantauan secara berkala. Kami memberikan kartu aktivitas selama pandemi, kemudian dilakukan kontrol masyarakat selama 15 hari serta pemberian kuesioner tentang pemahaman protocol kesehatan.

Beberapa seputar pertanyaan kuesioner diantaranya: 1) apakah peserta memahami tentang pentingnya protokol kesehatan sebelum kegiatan pengmas? 2) apakah peserta memahami tentang pentingnya protokol kesehatan setelah kegiatan pengmas? 3) apakah peserta sering melaksanakan protokol kesehatan sebelum kegiatan oengmas? 4) apakah peserta sering melaksanakan protokol kesehatan setelah kegiatan pengmas? 5) apakah peserta ikut mengajak orang sekitar untuk melaksanakan protokol kesehatan?

Data diperoleh dari 15 warga yang tergabung dalam kegiatan kemudian diolah dengan statistic sederhana.

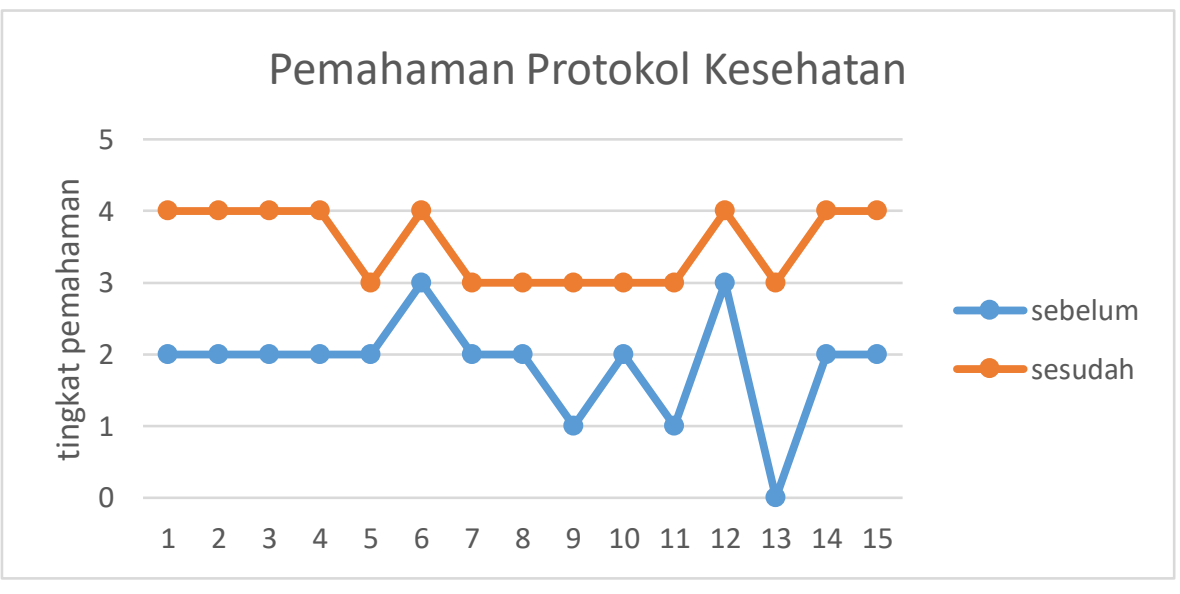

Table 4.1 Pemahaman Protokol Kesehatan.

Garis biru menggambarkan pemahaman peserta tentang protocol kesehatan sebelum adanya kegiatan pengmas. Garis oranye menggambarkan pemahaman peserta setelah adanya kegiatan pengmas. Dari Tabel 4.1 diketahui bahwa pemahaman peserta yang terlibat dalam kegiatan pengmas sebelum adanya kegiatan menunjukkan tingkat yang cukup rendah atau banyak yang belum memahami tentang protocol kesehatan dengan tepat. Setelah adanya kegiatan pengmas, diagram menujukkan peningkatan pengetahuan peserta tentang protocol kesehatan sebesar $87 \%$. 


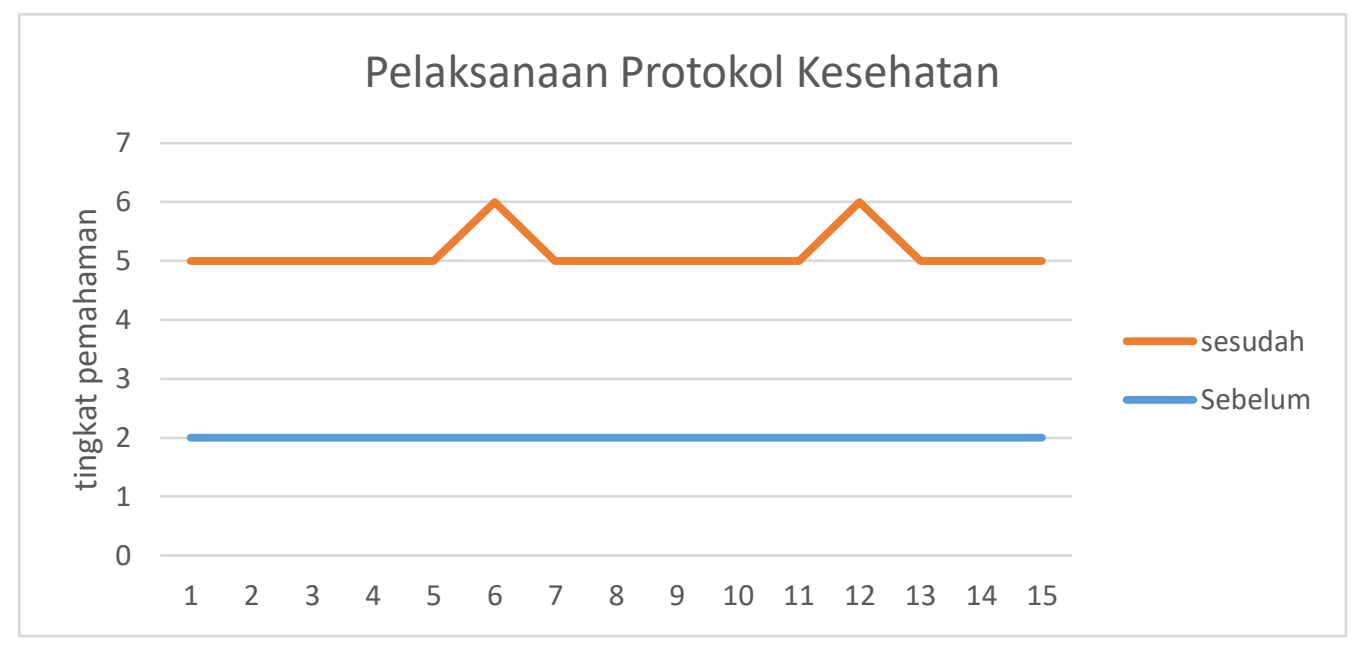

Tabel 4.2 Pelaksanaan Protokol Kesehatan

Diagram biru menggambarkan penerapan peserta dalam menggunakan protokol kesehatan sebelum kegiatan pengmas, diagram oranye menggambarkan penerapan peserta dalam menggunakan protocol kesehatan setelah kegiatan pengmas.

Berdasarkan Tabel 4.2 diketahui bahwa peserta pengmas mengalami peningkatan antusias dalam menggunakan protokol kesehatan sebesar $55 \%$ setelah mengikuti kegiatan pengmas. Setelah evaluasi, 3 dari 15 peserta mau mengajak tetangga lain untuk mematuhi protocol kesehatan. Beberapa diantaranya, peserta mau membagikan masker gratis untuk tetangga maupun saudara terdekat.

Hasil dari efisiensi kartu aktivitas untuk anak dan orang tua masih belum semua melaksanakan dikarenakan hanya efektif 3 sampai 5 hari dari 15 hari. Alasannya, mereka lebih menyukai melakukan aktivitas tanpa ada kartu yang mengikat.

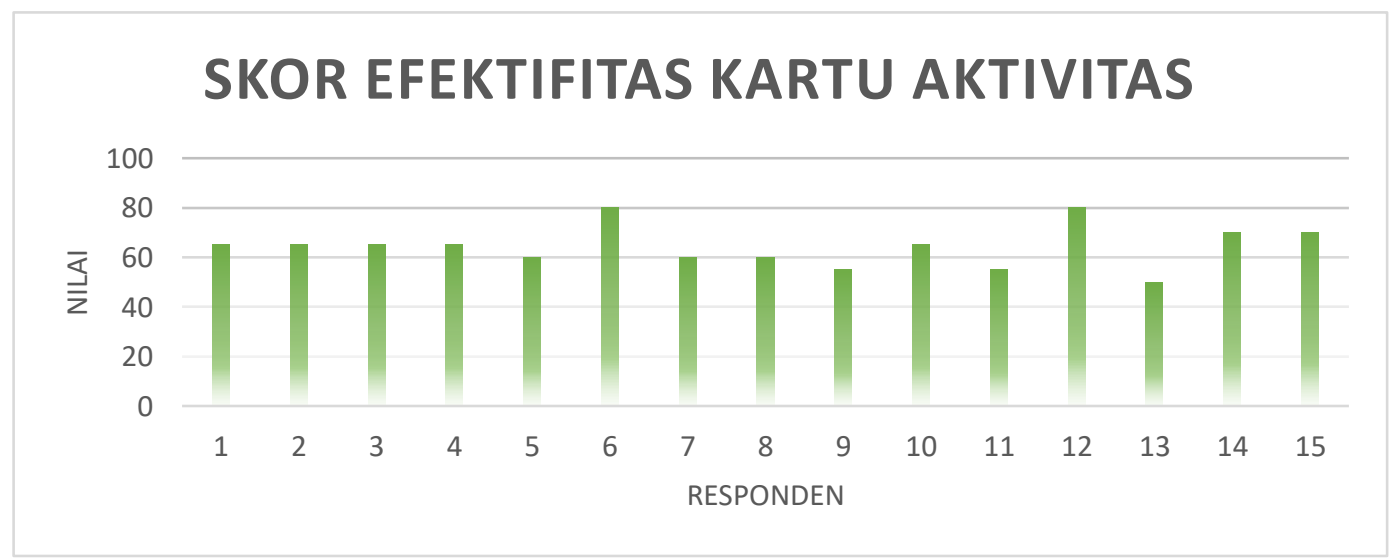

Tabel 4.3 Efektifitas kartu aktivitas selama pandemi.

Dari tabel di atas menunjukkan hanya beberapa peserta yang menerapkan dalam beberapa hari. Kartu aktivitas selama pandemi ditujukan untuk mengatur kegiatan antar anak dan orang tua selama pandemi agar dapat menjalani aktivitas sehari-hari dengan optimal. Banyak anak yang mengeluhkan perlakuan orang tua selama di rumah sehingga mereka merasa tidak nyaman, sebaliknya orang tua mengeluhkan kegiatan anak selama di rumah yang kurang aktif. 
Efektifitas kartu aktivitas pandemi belum diterapkan dengan optimal oleh warga baik orang tua dan anak, sehingga hasil efektifitas hanya ada $2 \%$ dari sebelum penggunaan kartu. Dari 15 peserta, 5 orang tua yang memiliki anak usia 5-15 tahun, baik laki-laki maupun perempuan, menyatakan, anak perempuan jauh lebih bisa terkendali, sedangkan anak laki-laki susah untuk dikendalikan (sering bermain gadget dan jarang olahraga), 1 peserta dengan anak laki-lakinya hanya mampu bertahan 5 hari untuk menerapkan kartu aktivitas pandemi, dan ada sedikit perubahan, namun selebihnya kembali pada kebiasaan buruknya.

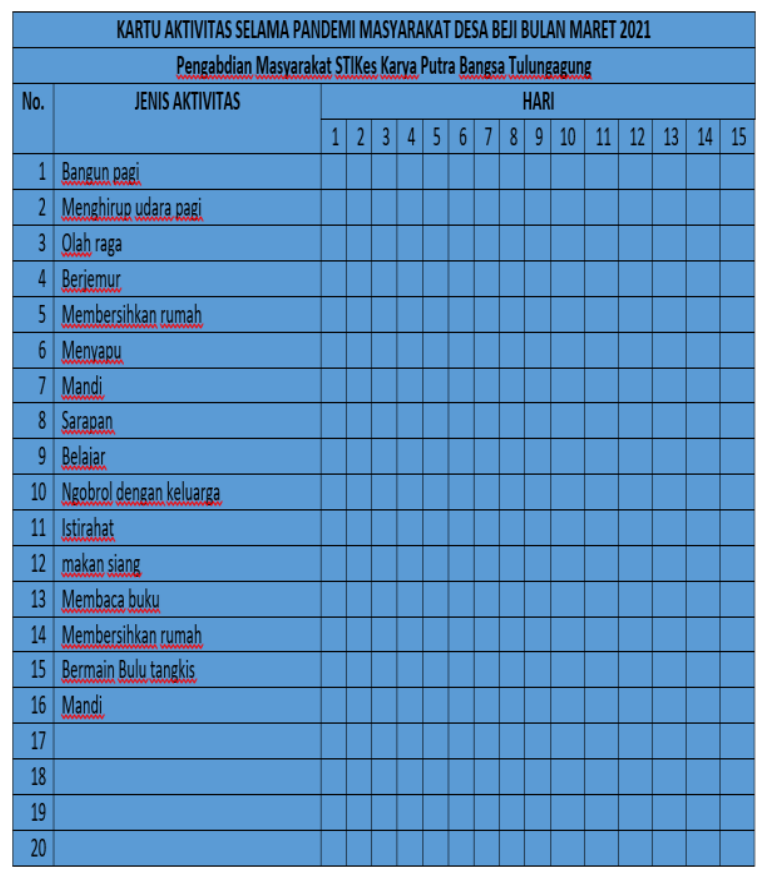

Gambar 1 Kartu Aktivitas Pandemi. Kartu yang digunakan untuk mengatur aktivitas selama pandemi agar lebih optimal.

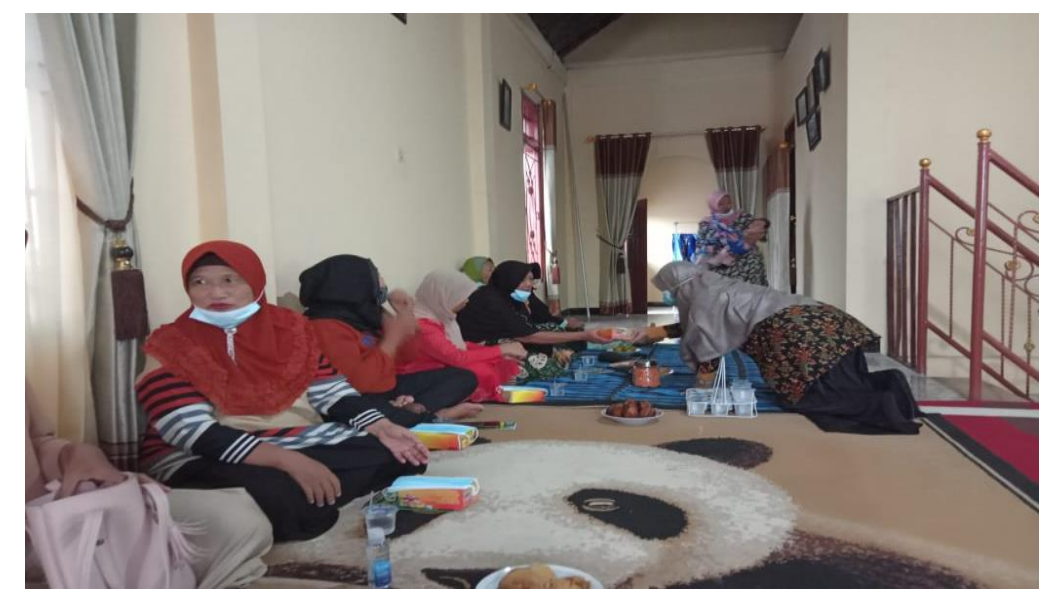

Gambar 2 Foto Kegiatan Pengabdian Masyarakat 

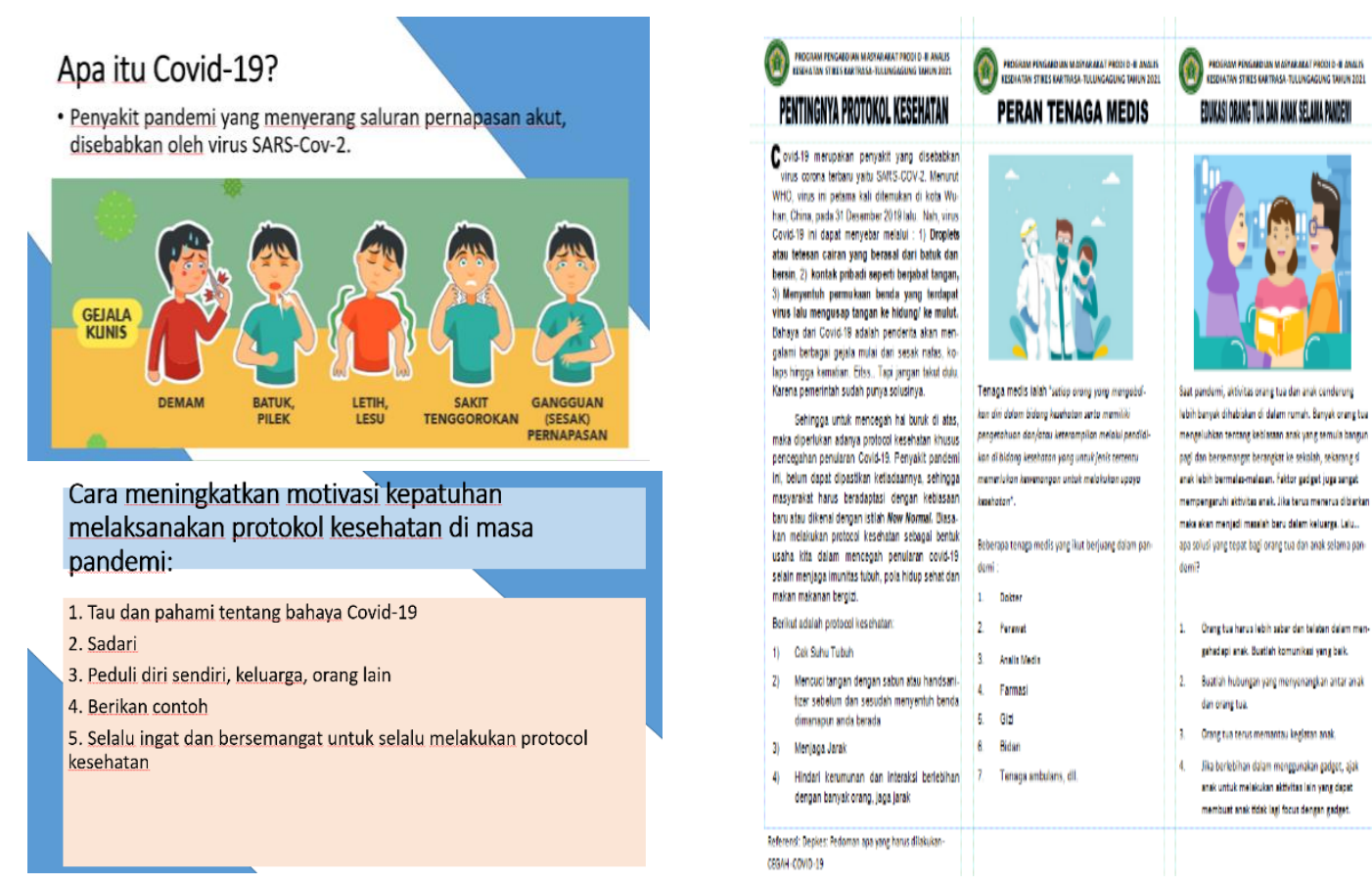

Gambar 3 Materi slide dan Isi Leaflet Pengabdian Masyarakat

\section{KESIMPULAN}

Setelah dilakukannya program pengabdian masyarakat tentang Strategi Peningkatkan Semangat Dan Kesadaran Masyarakat Dalam Menerapkan Protokol Kesehatan Dengan Kartu Aktivitas Selama Pandemi Covid-19 maka di dapatkan hasil sebagai berikut: 1 ) masyarakat mengalami peningkatan pemahaman tentang pentingnya penggunaan protocol kesehatan secara tepat setelah kegiatan pengmas, 2) masyarakat sangat antusias menerapkan protocol kesehatan secara tepat dan mau mengajak orang lain dalam menerapkan protocol kesehatan yang tepat 3) kartu ajtivitas pandemi belum maksimal dapat diterapkan oleh peserta masyarakat karena berbagai factor kesibukan.

\section{UCAPAN TERIMA KASIH}

Penulis mengucapkan terima kasih kepada STIKes Karya Putra Bangsa Tulungagung sebagai pihak yang telah memberi dukungan financial terhadap pelaksanaan kegiatan ini.

\section{DAFTAR PUSTAKA}

Ayu, G., Laksmi, P., \& Sari, P. (2020). Coronavirus Disease 2019 (COVID-19). Journal of Midwifery and Women's Health, 65(6), 833-834. https://doi.org/10.1111/jmwh.13196

Beji, unit kepala desa. (2021). Profil Desa Beji. http:/ / beji.tulungagungdaring.id/profil

Dinkes. (2021). Perkembangan kasus Covid-19 di Kabupaten Tulungagung Januari 2021. http: / / dinkes.tulungagung.go.id/?p=1170

Nasruddin, R., \& Haq, I. (2020). Pembatasan Sosial Berskala Besar (PSBB) dan Masyarakat Berpenghasilan Rendah. SALAM: Jurnal Sosial Dan Budaya SyarI, 7(7). https://doi.org/10.15408/sjsbs.v7i7.15569 
RI, K. (2021). PMK No 10 Tahun 2021 Tentang Pelaksanaan Vaksinasi dalam Rangka Penanggulangan Pandemi Corona Virus Disease 2019 (COVID-19). Permenkes Rl, 2019, 33. https://persi.or.id/wpcontent/uploads/2021/02/pmk10-2021.pdf

Satgas Penanganan COVID-19. (2020). Analisis Data COVID-19 Indonesia Update Per 03 Januari 2021. Satuan Gugus Tugas Penanganan COVID-19 Indonesia, (January), 1-174.

Shereen, M. A., Khan, S., Kazmi, A., Bashir, N., \& Siddique, R. (2020). COVID-19 infection: Origin, transmission, and characteristics of human coronaviruses. Journal of Advanced Research, 24(April), 91-98. https://doi.org/10.1016/j.jare.2020.03.005

Tarigan, I. L., \& Arum, K. (2020). Modulation of severe acute respiratory syndrome coronavirus (SARS-CoV-2) in receptor, innate immunity and drug antiviral candidate. Jurnal Teknologi Laboratorium, 9(1), 1-12. https: / / doi.org/10.29238/teknolabjournal.v9i1.214

Zainaro, M. A., Andoko, A., \& Rahmawati, R. P. (2021). Hubungan Pengetahuan dan Sikap Terhadap Kejadian Covid-19 pada Masyarakat di Kelurahan Mulyojati Kota Metro. Malahayati Nursing Journal, 3(4), 517-528. 